\title{
Pseudocyst of Pancreas, Rare Crisis in Sickle Cell Disease
}

\author{
Amrutha Garikapati1 ${ }^{1}$, Sunil Kumar ${ }^{2}$, Anuj Chaturvedi ${ }^{3}$, Charan Singh Bagga ${ }^{4}$
}

${ }^{1}$ Department of Medicine, Jawahar Lal Nehru Medical College, Datta Meghe Institute of Medical Sciences (Deemed to Be University, Wardha, Maharashtra, India. ${ }^{2}$ Department of Medicine, Jawahar Lal Nehru Medical College, Datta Meghe

Institute of Medical Sciences (Deemed to Be University, Wardha, Maharashtra, India. ${ }^{3}$ Department of Medicine, Jawahar Lal Nehru Medical College, Datta Meghe Institute of Medical Sciences (Deemed to Be University, Wardha, Maharashtra, India. ${ }^{4}$ Department of Medicine, Jawahar Lal Nehru Medical College, Datta Meghe Institute of Medical Sciences (Deemed to Be University, Wardha, Maharashtra, India.

\section{INTRODUCTION}

Sickle cell syndrome is an inherited autosomal recessive disease which results in the production of abnormal haemoglobin $\mathrm{S}$ due to a point mutation in the beta globin gene that changes the sixth amino acid from glutamic acid to valine ( $\alpha 2 \beta 26$ $\mathrm{Glu} \rightarrow$ Val).[1] These deformed RBCs cause vaso-occlusion, tissue ischemia, and infarction leading to clinical manifestations. About $10 \%$ of sickle cell patients present with acute abdominal pain, which may be due to acute cholecystitis, acute pancreatitis (rare), peptic ulcer disease, constipation due to opioids, hepatic and splenic sequestration, urinary tract infections and ischaemic bowel.[2,3,4]

On literature search, not a single case of pseudo pancreatic cyst as a complication of sickle cell disease has been reported. We present a rare case of vaso-occlusive crisis in a 40 year old male patient with sickle cell anaemia leading to acute ischemic pancreatitis which may not be identified at initial stages as he was treated with fluids for sickle cell crisis similar to acute pancreatitis later on diagnosed as pseudo cyst pancreas.

Pancreatic pseudocyst in a sickle cell disease is commonly misdiagnosed as sickle cell crisis hence causing difficulty in establishing the diagnosis, especially if abdominal pain is the presenting complaint. We present a case of 40-year-old nonalcoholic male having complaints of pain abdomen, misdiagnosed as peptic ulcer disease turned out to be pseudocyst of pancreas on ultrasonography of abdomen.

\section{PRESENTATION OF CASE}

A 40-year-old male patient labourer by occupation from rural background was admitted with diffuse upper abdominal pain since one week, along with off and on vomiting. He was a known case of sickle cell disease diagnosed 2 years back, on irregular treatment from a general practitioner. He also gave history of multiple blood transfusions in the past and had recurrent admission for joint pain, abdominal discomfort, resolved by conservative management. He was not an alcoholic or smoker. He denied any history of diabetes mellitus, hypertension in the past. In his Family, her mother was having sickle cell disease.

On physical examination, the patient was having mild temperature as $38.7{ }^{\circ} \mathrm{C}$, pulse 108 beats/minute, respiratory rate was 18/minute, and blood pressure 98/60 mmHg in right arm supine position. Pallor and mild icterus were present.

On abdominal examination, there was mild tenderness and fullness in epigastric area. Spleen and liver were not palpable. Bowel sounds were normal. The remainder of the physical examination was normal.
Corresponding Author: Amrutha Garikapati, Department of Medicine, Jawahar Lal Nehru Medical College, Datta Meghe Institute of Medical Sciences (Deemed to Be University, Wardha, Maharashtra, India.

E-mail: ammu.garikapati@yahoo.com

DOI: $10.14260 / \mathrm{jemds} / 2020 / 451$

How to Cite This Article:

Garikapati A, Kumar S, Chaturvedi A, et al. Pseudocyst of pancreas, rare crisis in sickle cell disease. J. Evolution Med. Dent. Sci. 2020;9(29):2072-2073, $10.14260 /$ jemds $/ 2020 / 451$

Submission 17-04-2020,

Peer Review 09-06-2020,

Acceptance 16-06-2020,

Published 20-07-2020.

Copyright (C) 2020 JEMDS. This is an open access article distributed under Creative Commons Attribution License [Attribution 4.0 International (CC BY 4.0)] 
His blood parameters on admission showed haemoglobin of $7.6 \mathrm{~g} / \mathrm{dL}$, mean corpuscular volume $70 \mathrm{fl}$, total leukocyte count of $9600 / \mathrm{cu} \mathrm{mm}$ and platelet count 2.27 lakhs/cu mm. His biochemical tests showed blood urea $30 \mathrm{mg} / \mathrm{dL}$, serum creatinine $0.8 \mathrm{mg} / \mathrm{dL}$, serum sodium $134 \mathrm{mmol} / \mathrm{L}$, serum potassium $3.7 \mathrm{mmol} / \mathrm{L}$; serum amylase $120 \mathrm{IU} / \mathrm{L}$, serum lipase $100 \mathrm{IU} / \mathrm{L}$. His liver function test revealed serum bilirubin 3 $\mathrm{mg} / \mathrm{dL}$, unconjugated $2.1 \mathrm{mg} / \mathrm{dL}$, conjugated $0.9 \mathrm{mg} / \mathrm{dL}$, alanine transaminase $42 \mathrm{IU} / \mathrm{L}$, aspartate transaminase 56 $\mathrm{IU} / \mathrm{L}$, alkaline phosphatase $172 \mathrm{IU} / \mathrm{L}$, total proteins $5.9 \mathrm{~g} / \mathrm{dL}$, serum albumin $3.5 \mathrm{~g} / \mathrm{dL}$.

In view of abdominal tenderness and mild rise of serum amylase, computerised tomography of abdomen was done which revealed mild pancreatitis with large pseudocyst of pancreas and there was no evidence of any hepatobiliary disease. [Figure 1]

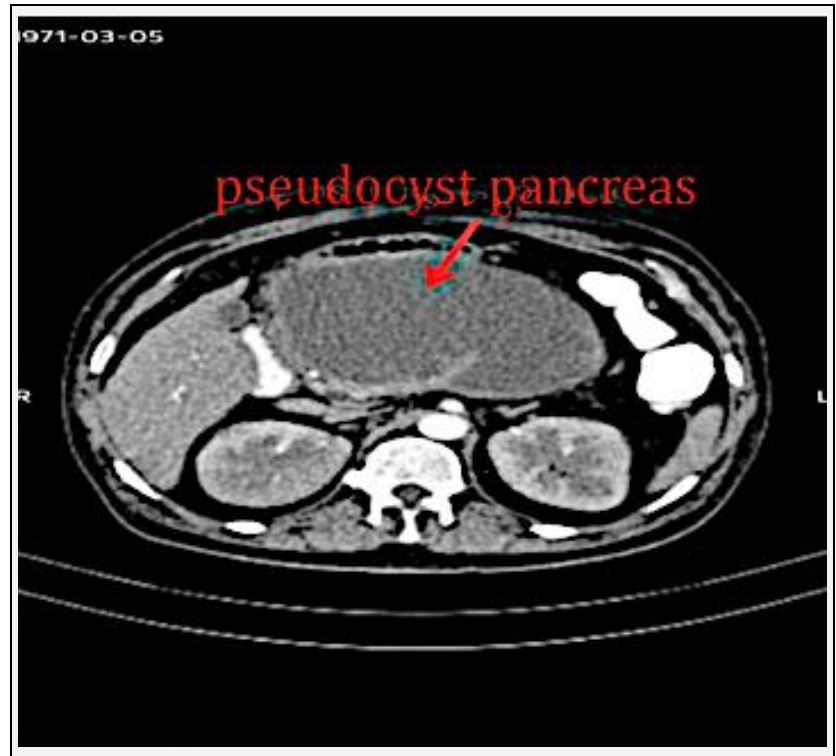

Figure 1. Computerised Tomography of Abdomen with Large Pseudocyst of Pancreas (Red Arrow)

CT abdomen-pelvis was dome for confirmation of pseudocyst and CT guided percutaneous drainage of the pancreatic cystic structure revealed brown fluid with blood cell and high amylase and LDH content $(344 \mathrm{U} / \mathrm{L}$ and $1,670 \mathrm{IU} / \mathrm{L}$, respectively). These findings were consistent with a pancreatic pseudocyst. Fluid was drained by placing a pigtail catheter percutaneously into the fluid cavity. His pain abdomen subsided after two days. Patient was treated for sickle cell crisis with fluids and conservative management. There was no complication and progression of size of the cyst after repeat sonography. On regular follow up every month patient was doing well.

\section{DISCUSSION}

Pancreatic pseudocyst is a type of cystic tumour having wall without an epithelial lining and black cystic fluid with a high concentration of amylase, which commonly occurs as a complication of acute/chronic pancreatitis, pancreatic injuries and pancreatectomy.[1] Some case had been reported in Systemic Lupus Erythematosus. [5] In most of the cases, there is having evidence of Pancreatitis. Few cases of pancreatitis in patients with Sickle cell disease had been reported but without pancreatic pseudocyst.[3,4] Surprisingly, even in text book pancreatic pseudocyst is not included as a cause of abdominal pain in sickle cell crisis.[6]

Exact mechanism is not clear but some of the authors hypothesized that the pancreatitis may be the initial insult which was due to endothelial damage caused by microthrombi formation and ischemia.[3,4] In sickle cell due to stiff red cell membrane, increased viscosity, and dehydrated cell because of potassium leakage and calcium influx, it loses the pliability needed to traverse small capillaries and also possess altered "sticky" membranes that are abnormally adherent to the endothelium of small venules.[6] These pathophysiology leads to microvascular vaso-occlusion and premature haemolysis. Recurrent haemolysis may lead to gall bladder sludge or pigment stone which may be unnoticed, further provoking ischemic pancreatitis and thence pseudocyst of pancreas. The rigid adherent cells clog small capillaries and venules, causing tissue ischemia, acute pain, and gradual end-organ damage, like pancreatitis.[6] In our case there was similar history in the past 2 years with recurrent hospital admission may be due to acute pancreatitis with lead to the following pseudocyst.

\section{CONCLUSIONS}

Our case helps to raise awareness regarding the importance of considering acute pancreatitis and pseudo cyst of pancreas which may be life threatening in patients with SCD. Timely diagnosis is imperative owing to a different treatment approach in this patient population.

\section{REFERENCES}

[1] Habashi S, Draganov PV. Pancreatic pseudocyst. World J Gastroenterol 2009; 15(1):38-47.

[2] Ware RE, de Montalembert M, Tshilolo L, et al. Sickle cell disease. Lancet 2017; 390(10091):311-23.

[3] Hasan B, Asif T, Braun C, et al. Pancreatitis in the setting of vaso-occlusive sickle cell crisis: a rare encounter. Cureus 2017; 9(4):e1193.

[4] Ahmed S, Siddiqui AK, Siddiqui RK, et al. Acute pancreatitis during sickle cell vaso-occlusive painful crisis. Am J Hematol 2003; 73(3):190-3.

[5] Kumar S, Diwan SK, Parihar PH. Pancreatic pseudocyst as presenting feature in systemic lupus erythematosus. Online J Health Allied Sci 2014; 13(1):13.

[6] Benz EJ. Disorders of hemoglobin. In: Jameson JL, Fauci AS, Kasper DL, et al, eds. Harrison's principles of internal medicine. 20th edn. New York: McGraw-Hill 2018: p. 692. 